\title{
Bone-specific master transcription factor Runx2 regulates signaling and metabolism related programs in osteoprogenitors
}

\author{
N. M. Teplyuk ${ }^{1,2}$, V. I. Teplyuk \\ ${ }^{1}$ University of Massachusetts Medical School \\ 55, Lake Ave North, 01655, Worcester, MA, USA \\ ${ }^{2}$ Institute of Molecular Biology and Genetics of National Academy of Sciences of Ukraine \\ 150, Zabolotnogo str., Kiev, Ukraine, 03680 \\ Nadiya.teplyuk@umassmed.edu
}

\begin{abstract}
Aim. Runx2 (AML3) transcription factor is the key regulator of osteoblastic lineage progression and is indispensable for the formation of mineral bones. Runx2 expression increases during differentiation of osteoblasts to induce osteoblast-specific genes necessary for the production and deposition of bone mineral matrix. However, Runx 2 is also expressed at a lower level in early osteoprogenitors, where its function is less understood. Here we study how Runx2 determines the early stages of osteoblastic commitment using the model system of Runx2 re-introduction in mouse calvaria cells with Runx2 null background. Method. Affymetrix analysis, Western blot analysis and quantitative real-time reverse transcriptase PCR ( $q R T-P C R$ ) analysis were employed. Results. Gene expression profiling by Affymetrix microarrays revealed that along with the induction of extracellular matrix and bone mineral deposition related phenotypic markers, Runx 2 regulates several cell programs related to signaling and metabolism in the early osteoprogenitors. Particularly, Runx 2 regulates transcription of genes involved in G-protein coupled signaling network, FGF and BMP/TGF beta signaling pathways and in biogenesis and metabolism pathways of steroid hormones. Conclusion. The data indicate that the lineage specific program, regulated by the master regulatory transcription factor, includes the regulation of cellular signaling and metabolism which may allow the committed cell to react and behave differently in the same microenvironment.
\end{abstract}

Keywords: osteoblast progenitors, Runx2, signaling.

Introduction. Bone development, repair and remodeling homeostasis require constant differentiation of mesenchymal stem cells through osteoprogenitors to mature osteoblasts and osteocytes. Consistent with the recent discoveries that a cell fate can be programmed by only few master transcriptional regulators, the cell fate along osteoblastic lineage is regulated by Runx 2 and Osterix factors, both indispensable for bone formation $[1,2]$.

Runx 2 factor regulates expression of multiple target genes via direct activation and repression of genes

(C) Institute of Molecular Biology and Genetics NAS of Ukraine, 2010 transcription or by epigenetic remodeling of gene regulatory sequences [3].

Multiple Runx2 target genes are responsible for bone mineral production at the late stages of osteoblasts maturation. However, Runx2 expression starts very early along osteoblastic lineage, and its role at the early steps of osteogenic commitment is scarcely understood. This research is focused on the fundamental mechanisms of osteoprogenitors programming by Runx2. We have compared the transcriptomes of Runx2 null osteoprogenitor cells before and after their reconstitution with wild type Runx 2 protein or its non-functional mutant using Affymetrix microarrays. We have 
found that several clusters of functionally related genes respond to Runx2 re-introduction. They include the genes related to the osteoblast-specific signaling network, hormones biosynthesis and general metabolism. These genes define osteoblast cell identity in the bone microenvironment.

Materials and methods. Cell culture and adenovirus infections. Runx2 null calvaria osteoprogenitors cell line was developed previously from the fetal calvarial region of Runx 2 knock-out mice by stable integration of Tert [4]. Runx2 null cells were maintained in aMEM supplemented with $10 \%$ fetal bovine serum (FBS) («Atlanta Biologicals», USA), $30 \mathrm{mM}$ penicillin-streptomycin and $100 \mathrm{mM} \mathrm{L}$-glutamine at $37^{\circ} \mathrm{C}$ and $5 \% \mathrm{CO}_{2}$ humidified atmosphere. Adenoviral vectors containing cDNAs of full length Runx2 and its Cterminal deletion mutants 1-361 $(\Delta \mathrm{C})$ were each transferred into the AdenoVator ${ }^{\mathrm{TM}}$ expression construct («Qbiogene», USA) from the corresponding pcDNA expression vectors described previously.

Cells were plated for infections in 6-well plates $\left(12.5 \cdot 10^{4}\right.$ cells/well). After $24 \mathrm{~h}$, cells were infected with $100 \mathrm{MOI}$ of each virus in $600 \mu \mathrm{l}$ of $\alpha \mathrm{MEM}$ media complemented with $1 \%$ FBS for $4 \mathrm{~h}$. Upon addition of $400 \mu \mathrm{l}$ media containing $1 \% \mathrm{FBS}$, cells were incubated for additional $10 \mathrm{~h}$.

Affymetrix analysis. Total RNA for Affymetrix analysis (and subsequent qRT-PCR validation) was isolated with Trizol reagent and purified using the RNeasy Mini Kit («Qiagen», USA). Analysis of gene expression using Mouse Genome 430 2.0 Array was performed as described earlier [5]. Data processing and sample comparisons were performed using an open source library for statistical analysis (BioConductor library for R environment; http://www.bioconductor. org). Following Robust Multi-array Average expression measurement (RMA) and background correction, the array values were subjected to quantile normalization assuming identical signal distributions in each of the arrays. Statistically significant differences between probe sets were evaluated using Student's T test $(\mathrm{p}<$ $<0.05$ ). Functional annotation of Affymetrix probe sets and gene ontology relationships between groups of coregulated genes were assessed using the Database for Annotation, Visualization and Integrated Discovery (DAVID 2.0) (http://david.abcc.ncifcrf.gov) [6].
Western blot analysis. Cell lysates were prepared from cell pellets that were boiled in $100 \mu$ of Direct Lysis buffer (50 mM Tris-HCl, pH 6.8, 2 \% SDS, $10 \%$ Glycerol, $12 \%$ Urea, $25 \mu \mathrm{M}$ MG132, 100 mM DTT and $1 \times$ Complete protease inhibitors) («Roche», USA). Aliquots of each lysate $(5 \mu \mathrm{l})$ were separated in $10 \%$ sodium dodecyl sulfate (SDS)-polyacrylamide gel electrophoresis (PAGE). Proteins were transferred using semi-wet blotting to nitrocellulose membranes («Millipore», USA). Phosphatase buffered saline (PBS) with $5 \%$ non-fat milk was used for $1 \mathrm{~h}$ at room temperature to block non-specific protein binding. Primary and secondary antibodies were used at 1:2,000 dilutions for $1 \mathrm{~h}$ room temperature in PBS/0.1\% Tween (PBST) with $1 \%$ milk. Signal was detected with ECL (Perkin Elmer Western Lighting Chemiluminescence Reagent Plus, «Perkin Elmer», USA). RUNX2specific mouse monoclonal antibodies were a generous gift of Dr. Yoshiaki Ito (Institute for Molecular and Cellular Biology, Singapore). CDK2 rabbit polyclonal antibodies (SC-163) were purchased from Santa Cruz Biotechnology, Santa Cruz, USA.

Quantitative real-time reverse transcriptase PCR ( $q R T-P C R)$ analysis. qRT-PCR was performed to validate changes for the sub-set of Runx2 responsive genes. Specific qPCR primers were designed using Primer 3 software. Total RNA for qRT-PCR assays was isolated as described, subjected to DNaseI digestion and purified using an RNA purification kit («Zymogen», USA). Aliquots of RNA $(1 \mu \mathrm{g})$ were used for reverse transcription (First strand cDNA synthesis kit, «Invitrogen», USA) with random hexamer primers. Quantitative PCR was performed with Power SYBR Green PCR Master Mix («Applied Biosystems», USA) using an automated system (Applied Biosystems 7300 Real Time PCR System) with 0.5 pmoles $/ \mu$ of the specific gene primers.

Results and discussion. Functional clustering of Runx 2 responsive genes in osteoprogenitors. To investigate Runx2 involvement in the programming of osteoprogenitors, we used the model system of early mouse calvaria osteoprogenitors with Runx 2 null background. These cells are blocked at the very early stage of osteogenic lineage because of the absence of Runx 2 gene; although they deposit collagen into extracellular matrix, they do not express other phenotypic mar- 


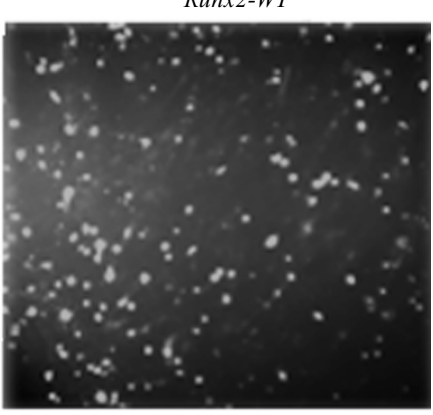

$B$

Protein:

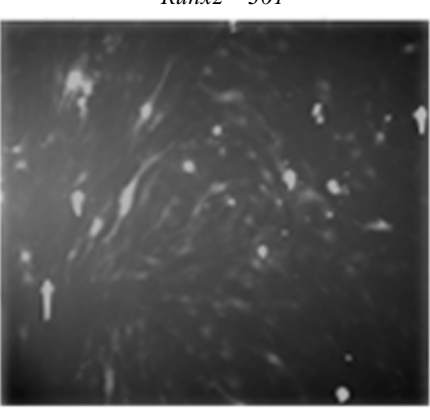

C

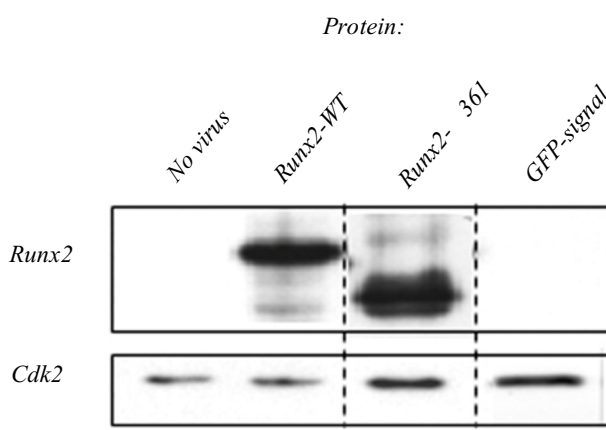

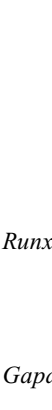

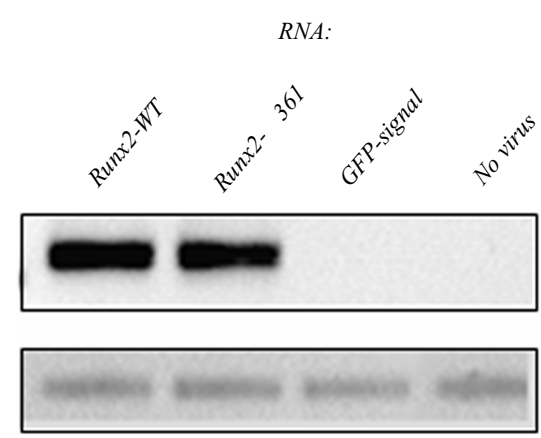

Fig. 1. Runx2 overexpression in Runx2 null mouse calvaria cells: $A-$ Runx2 wild type (WT), C-terminal truncated Runx2 mutant (aa 1$361, \Delta C)$ or GFP control protein were expressed via adenoviral infections in Runx2 null cells (equal infection efficiency was determined by GFP signal); $B, C$ - exogenous Runx2 protein and RNA expression levels were detected by Western blot and RT-PCR respectively kers and are not able to differentiate and mineralize in osteogenic media (ascorbic acid and beta-glycerophosphate). After cells reconstitution with exogenously expressed Runx 2 protein the block is released and cells progress along osteoblatic lineage, differentiate to normal osteoblasts and mineralize in osteogenic media.

To assess the global changes in gene expression during the osteoblatic lineage the genome-wide Affymetrix expression profiling was performed with the investigated cells reconstituted with either wild type (WT) Runx 2 protein or with its C-terminally truncated deletion mutant (Runx2- $\Delta \mathrm{C}$ ), which is non-functional because of the absence of transactivation and repression domains (Fig. 1).

Data analysis after Runx2 WT and Runx2- $\Delta \mathrm{C}$ introduction revealed total 1828 probe-sets and 1438 up- and down-regulated genes (with more than 1.4 fold changes, $\mathrm{p}<0.05)$ (Table). Functional clustering of these genes has shown that several clusters of functionally related genes are responsive to Runx2 introduction, and include the genes related to cell signaling pathways, general metabolism, transport, cell cycle and osteoblast phenotype. The changes in expression of selected subset of 180 genes were validated by quantitative PCR (qPCR) analysis and revealed a significant consistency with the data obtained by microarray.
Early osteoblast phenotypic genes are induced by Runx 2 in osteoblasts progenitors. As we expected, the functional clustering of results has shown that the genes of the early/middle osteoblast differentiation encoding Osteocalcin, Osteopontin, some collagens and Matrix metalloproteinases, were robustly induced by Runx 2 within 1 day after Runx 2 re-introduction (Fig. 2). The genes characteristic for the late differentiation stage encoding Bone sialoprotein, Alkaline phosphatase have not revealed detectable expression (data not shown).

Matrix metalloproteinases Mmp9, Mmp13 and some other collagen matrix processing enzymes (i. e. Lox12, Lox13, Tissue Inhibitors of Matrix Metalloproteinases Timp1 and Timp3) were robustly induced by Runx2, while others (i. e. Timp2) were inhibited. Consistently, a sub-set of bone-related Runx2 responsive genes like secreted phosphoprotein (Spp1, Osteopontin), Bone gamma-carboxyglutamate (Bglap1, Osteocalcin) were also up-regulated. Some genes in the list encode other master fate-determining transcription factor in osteoblasts acting up- and downstream of Runx2 protein (e. g. Core binding factor beta $(\mathrm{Cbfb}), \mathrm{Sp} 7$ or Osterix).

Runx2 programs bone-related signaling network in osteoprogenitor cell. Along with the cluster of osteo- 
The number of genes up- and down-regulated by Runx2 in osteoprogenitors

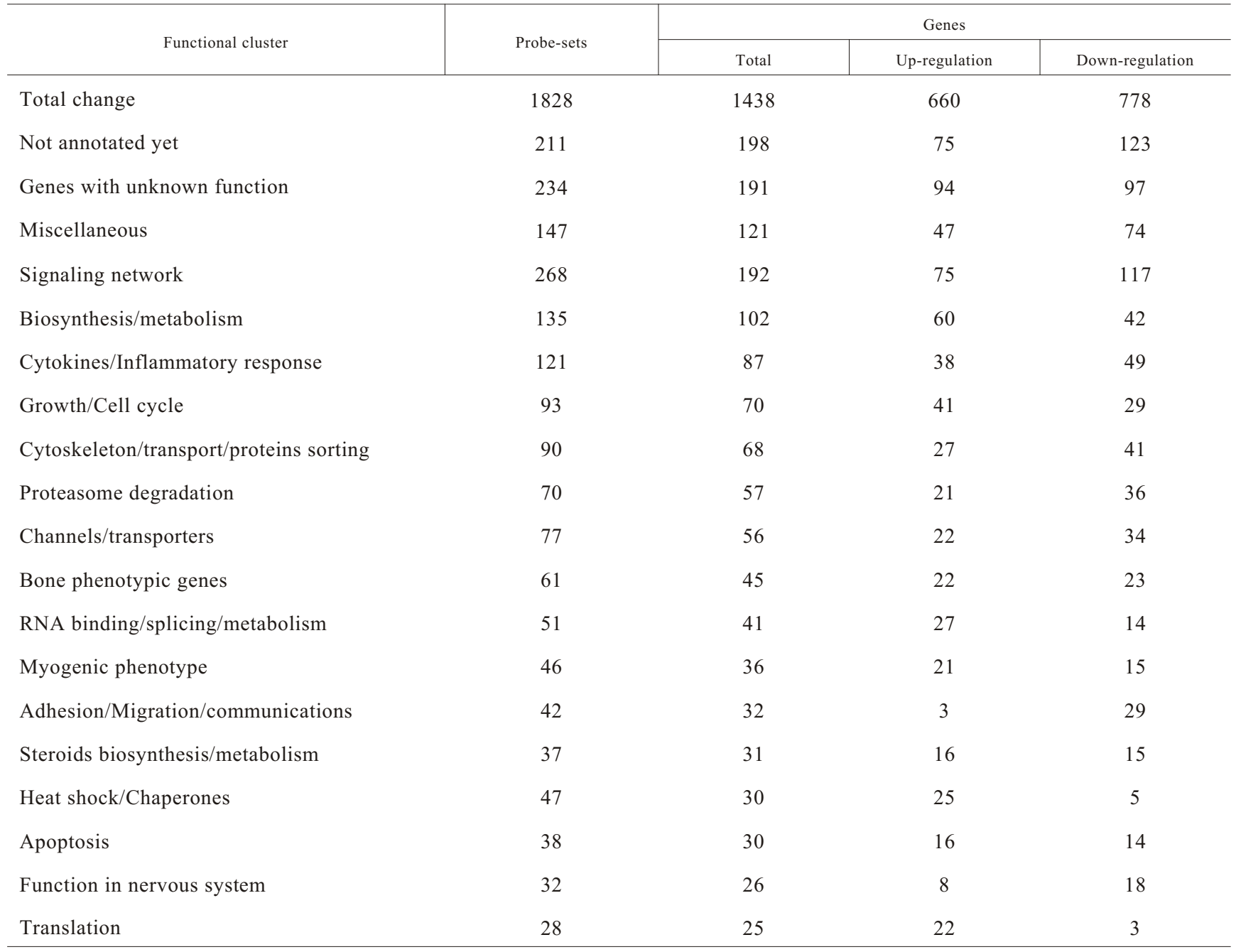

blast phenotypic gene markers, several other big clusters of interrelated genes were responsive to Runx 2 . The biggest of these clusters includes genes coding for cell signaling pathways, namely transmembrane receptors, extra- and intracellular modulators of their activity, cytoplasmic secondary messengers and the nuclear effectors. Among the most affected signaling pathways we identified all known critical signaling components in osteogenesis, including FGF, BMP/TGFbeta, Wnt and small G-proteins coupled signaling (e. g. PTH/ PTHrP, non-genomic steroid receptor Gpr30, cAMP signaling, growth factors FGF and EGF signaling).

We further arranged a sub-cluster of Runx 2 responsive genes related to G-protein coupled signaling in osteoblasts (Fig. 3). A bunch of G-protein coupled receptors and their interacting G-proteins are up- and down-regulated in osteoprogenitors. Some of these genes are known to play a role in osteoblastic cells (e. g. non-genomic Estrogen receptor Gpr30, Gper), while the function of other G-proteins coupled receptors (e. g. Gpr54, Gpr23) in bone has to be determined. The four of the Small Regulators of G-proteins (Rgss) are repressed by Runx2: Rgs2, 4, 5 and 16 (Fig. 3). Notably, Rgs2 and Rgs4 are known as molecular switches directing the signal along different ways from PTH/ PTHrP receptor $[7,8]$, the critical modulator of osteoblastic differentiation, growth and function [9]. Further investigation is needed to determine if these changes affect signaling pathway from PTH/PTHrP receptor during differentiation.

The second sub-cluster includes the extracellular matrix/proteoglycan genes known as the regulators of 
FGF, Wnt and BMP signaling, critical in the bone cells $[10,11]$. Heparane sulfate proteoglycanes (Syndecanes) physically interact with FGF receptors as well as FGF ligands and regulate signaling activity depending on the types of Heparane sulfate chains present [12]. The enzymes modifying chemical composition of Heparane sulfate chains components along with Proteoglycans co-repressors themselves are Runx2 responsive (Fig. 4), indicating that Runx2 plays a role as a modulator of the whole FGF signaling system.

Runx2 modulates steroid hormones biosynthesis and cholesterol metabolism machinery in osteoprogenitors. The second big cluster of genes responsive to Runx2 includes the genes responsible for cellular metabolism (Table), particularly for lipid/fatty acid, sugars and energy metabolism, red-ox homeostasis and cholesterol/steroid hormones biogenesis (Fig. 5). There are genes coding for the enzymes for several consecutive steps of cholesterol biosynthesis (Fdps, Lss, Cyp51, Dhcr) following by Cholesterol downstream conversion to Pregnenolone (Cyp11a1, Fdxr) are induced by Runx2. Interestingly, the genes related to bonecatabolic glucocorticoids signaling, including Glucocorticoid receptors $(\mathrm{Nr} 3 \mathrm{c} 1, \mathrm{Nr} 2 \mathrm{c} 2)$ and Glucocorticoid-induced gene (Gig1, Zfp704) are inhibited by Runx2 expression (Fig. 5). Taken together these data suggest that Runx 2 may promote the endogenous biogenesis of some anabolic steroid hormones derivatives of cholesterol in differentiating osteoblasts, while repressing signaling from catabolic glucocorticoids.

We performed genome-wide screening of the genes that are directly or indirectly regulated by the bone master regulatory transcription factor Runx 2 at the early stage of osteoblastic commitment. We found that several interrelated functional gene programs are architected by the presence of Runx 2 in osteoprogenitors, including early steps of bone matrix production, regulation of osteoblastic cell cycle, general metabolism, steroids biogenesis and the membrane/intracellular signaling network.

Genetic alterations of osteoblast specific signaling pathways that we have identified - FGF, PTH/PTHrP, BMP, TGF $\beta$ and Wnt signaling, cause hereditary syndromes with prominent bone abnormalities. Also, there are tremendous amount of accumulated evidences that each of above-mentioned signaling pathways plays a critical role in osteoblasts development and bone formation, both in vivo and in vitro [13].

Moreover, proper hormone signaling involving all classes of steroids is critical for bone development and homeostasis. For example deficiency of Estrogen or Androgen receptor leads to severe osteoporosis; deficiency of Vitamin D is well known to cause Rickets, while glucocorticoid treatment is associated with glucocorticoid-induced osteoporosis.

Taken together, these results guided us to a novel fundamental concept that the master transcriptional regulator (i. e. Runx2) changes representation of the total signaling network of the cell, and that such change may be a principal part of the fate-determining program to define cell identity in the environment. In other words, due to reprogramming its signaling network, Runx2 expressing osteoprogenitor reacts and behaves differently from its mother Mesenchymal stem cell in the same bone microenvironment, retaining the osteoprogenitor identity memory. The retention of such memory can be realized by chromatin remodeling (as Runx2 is a part of chromatin modification complexes) as well as by the retention of Runx 2 on mitotic chromosomes through progenitor cells generations.

At the same time, using bone as a model system, it is a part of broader biological problem of understanding the complete mechanism of cell specialization and (re)programming by master regulatory factors. Still far from understanding, this question is of the critical importance in the new and fast growing field of stem cell-based regenerative medicine, which has tremendous potential for improving both healthcare and human wellbeing.

\section{H. М. Теплюк, В. I. Теплюк}

Транскрипційний фактор Runx2 регулює генетичні програми, пов'язані із сигналінгом і метаболізмом попередників остеобластів

Резюме

Meта. Транскрипційний фактор Ruпх2 (AML3) є важливим регулятором диферениіаиї остеобластів, необхідним для формування кісток. Експресія гена Ruпх2 зростає в процесі диференціації остеобластів і призводить до активації остеобласт-специфічних генів, відповідальних за продукування мінерального матриксу. Мета роботи полягала у визначенні функиії гена Runх 2 у попередниках остеобластів, де він експресується на досить низькому рівні. Методи. Ми дослідили функиію гена Rипх2 на ранніх стадіях розвитку остеобластів 
за допомогою модельної системи Ruпх2-нокаутних клітин скальпів мишей, яким вводили ген Rипх2. Результати. При дослідженні експресії геному за допомогою Affymetrix чипів виявлено, щзо разом із індукиією фенотипових маркерів відкладання зовнішньоклітиного мінерального матриксу ген Rипх2 регулює декілька генетичних програм, пов'язаних із сигналінгом і метаболізмом попередників остеобластів. Зокрема, Runx2 регулює гени сигнальної мережі, зчепленої з $G$-білками, сигнальні иляхи FGF, BMP/TGF, а також ферментативні системи біосинтезу і метаболізму стероїдних гормонів. Висновки. Отримані дані вказують на те, щзо частина програми спеціалізації, яку виконує ключовий транскрипиійний фактор, складається з програмування сигнальних шляхів та метаболізму клітини, дозволяючи ранньоспеціалізованій клітині реагувати та функиіонувати певним чином у мікросередовищі.

Ключові слова: попередники остеобластів, Rипх2, сигналінг.

\section{Н. М. Теплюк, В. И. Теплюк}

Транскрипционный фактор Runx2 регулирует

генетические программы, связанные с сигналингом и

метаболизмом предшественников остеобластов

Резюме

Цель. Транскрипџионный фактор Ruпх2 (AML3) является ключевым регулятором дифференииачии остеобластов, необходимым для формирования костей. Экспресия гена Rипх2 повышается в проиессе дифференииации остеобластов, где он активирует остеобласт-специфические гены, необходимые для продукции минерального матрикса. Цель работы состояла в определении функиии гена Ruпx2 в ранних предшественниках остеобластов, где он экспрессируется на достаточно низком уровне. Методы. Мы исследовали, как Rипх2 функционирует на ранних стадиях специализации остеобластов с помощью модельной системы внедрения Runх2 в Rипх2-нокаутные клетки скальпа мыши. Результаты. При изучении экспресии генома с помощью Affymetrix чипов обнаружено, что вместе с индукиией фенотипичных маркеров, отвечающих за продукиию внеклеточного матрикса, Ruпx2 регулирует несколько генетических программ, связанных с сигналингом и метаболизмом остеобластов. В частности, Ruпх2 регулирует гены сигнальной сети, сиепленной с G-белками, сигнальных путей $F G F$, BMP/TGF, а также системы биосинтеза и метаболизма стероидных гормонов. Выводы. Полученные данные указывают на то, что программа специализачии, выполняемая ключевым транскрипционным фактором, включает программирование сигнальных путей и метаболизма клетки, позволяя раннедифференцированной клетке вести себя определенным образом в идентичной микросреде.

Ключевые слова: предшественники остеобластов, Rипх2, сигналинг.

\section{REFERENCES}

1. Komori T., Yagi H., Nomura S., Yamaguchi A., Sasaki K., Deguchi K., Shimizu Y., Bronson R. T., Gao Y. H., Inada M., Sato M., Okamoto R., Kitamura Y., Yoshiki S., Kishimoto T. Tar- geted disruption of $\mathrm{Cbfa} 1$ results in a complete lack of bone formation owing to maturational arrest of osteoblasts // Cell.1997.-89, N 5.-P. 755-764.

2. Nakashima K., Zhou X., Kunkel G., Zhang Z., Deng J. M., Behringer R. R., de Crombrugghe B. The novel zinc fingercontaining transcription factor osterix is required for osteoblast differentiation and bone formation // Cell.-2002.-108, N 1.-P. 17-29.

3. Lian J. B., Stein J. L., Stein G. S., van Wijnen A. J., Montecino M., Javed A., Gutierrez S., Shen J., Zaidi S. K., Drissi H. Runx2/Cbfa1 functions: diverse regulation of gene transcription by chromatin remodeling and co-regulatory protein interactions // Connect Tissue Res.-2003.-44, Suppl. 1.P. 141-148.

4. Bae J. S., Gutierrez S., Narla R., Pratap J., Devados R., van Wijnen A. J., Stein J. L., Stein G. S., Lian J. B., Javed A. Reconstitution of Runx2/Cbfa1-null cells identifies a requirement for BMP2 signaling through a Runx2 functional domain during osteoblast differentiation // J. Cell Biochem.-2007.100, N 2.-P. 434-449.

5. Teplyuk N. M., Galindo M., Teplyuk V. I., Pratap J., Young D. W., Lapointe D., Javed A., Stein J. L., Lian J. B., Stein G. S., van Wijnen $A$. $J$. Runx 2 regulates $G$ protein-coupled signaling pathways to control growth of osteoblast progenitors // J. Biol. Chem.-2008.-283, N 41.-P. 27585-27597.

6. Dennis G. Jr., Sherman B. T., Hosack D. A., Yang J., Gao W., Lane H. C., Lempicki R. A. DAVID: Database for Annotation, Visualization, and Integrated Discovery // Genome Biol.2003.-4, N 5.-P. 3.

7. Turner P. R., Mefford S., Christakos S., Nissenson R. A. Apoptosis mediated by activation of the $\mathrm{G}$ protein-coupled receptor for parathyroid hormone $(\mathrm{PTH}) / \mathrm{PTH}$-related protein (PTHrP) // Mol. Endocrinol.-2000-14, N 2.-P. 241-254.

8. Roy A. A., Nunn C., Ming H., Zou M. X., Penninger J., Kirshenbaum L. A., Dixon S. J., Chidiac P. Up-regulation of endogenous RGS2 mediates cross-desensitization between Gs and Gq signaling in osteoblasts // J. Biol. Chem.-2006.-281, N 43.-P. 32684-32693.

9. Kronenberg H. M. PTHrP and skeletal development // Ann. N. Y. Acad. Sci.-2006.-1068.-P. 1-13.

10. Jackson R. A., Nurcombe V., Cool S. M. Coordinated fibroblast growth factor and heparan sulfate regulation of osteogenesis // Gene.-2006.-379, N 1.-P. 79-91.

11. De Cat B., Semin D. G. Developmental roles of the glypicans // Cell Develop. Biol.-2001.-12, N 2.-P. 117-125.

12. Lamanna W. C., Kalus I., Padva M., Baldwin R. J., Merry C. L., Dierks T. The heparanome - the enigma of encoding and decoding heparan sulfate sulfation // J. Biotechnol.-2007.129, N 2.-P. 290-307.

13. Soltanoff C. S., Yang S., Chen W., Li Y. P. Signaling networks that control the lineage commitment and differentiation of bone cells // Crit. Rev. Eukaryot. Gene Exp.-2009.-19, N 1.P. 1-46. 
Figures to article by N. M. Teplyuk, V. I. Teplyuk

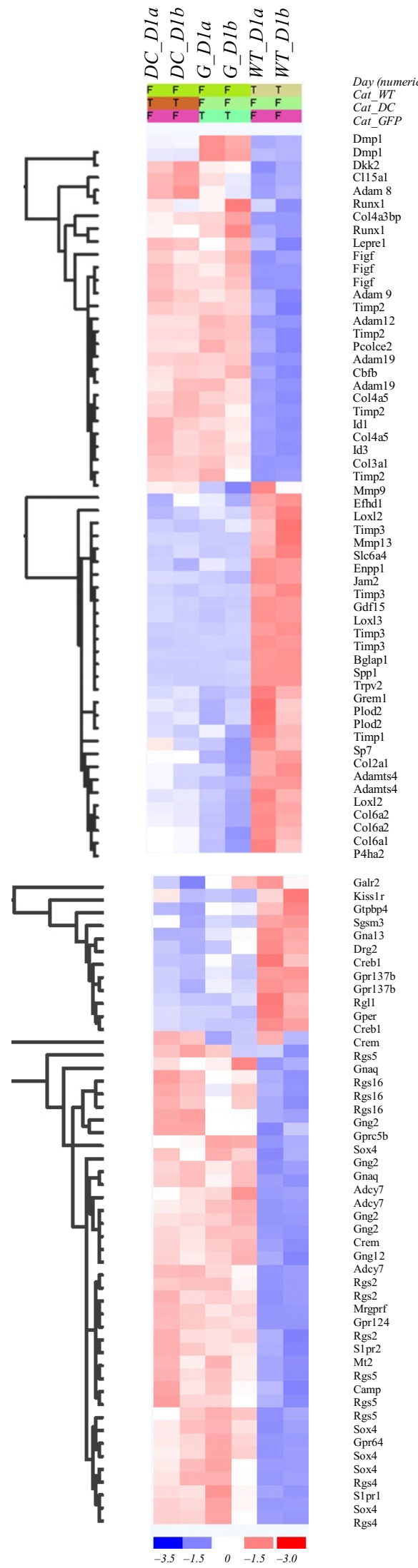

Dentin matrix protein 1

Dentin matrix protein

Dickkopf homolog 2

A disintegrin and metallopeptidase domain 8

Runt related transcription factor 1

Collagen, type IV, alpha 3 binding protei

Runt related transcription factor 1

Leprecan 1

C-fos induced growth factor

C-fos induced growth factor

A disintegrin and metallopeptidase domain 9 (meltrin gamma)

Tissue inhibitor of metalloproteinase 2

A disintegrin and metallopeptidase domain 12 (meltrin alpha)

Tissue inhibitor of metalloproteinase 2

Procollagen $\mathrm{C}$ - endopeptidase enchancer 2

A disintegrin and metallopeptidase domain 19 (meltrin beta)

Core binding factor beta

A disintegrin and metallopeptidase domain 19 (meltrin beta)

Tissue inhibitor of alpha 5

talloproteinase 2

Inhibitor of DNA binding 1
Collagen, type IV, alpha 5

Inhibitor of DNA binding

Collagen, type III, alpha 1

Tissue inhibitor of metalloproteinase 2

Matrix metallopeptidase 9

Lysyl oxidase-like 2

Tissue inhibitor of metalloproteinase 3

Matrix metallopeptidase 13

Solute carrier family 6 (neurotransmitter transporter, serotonin) member 4

Ectonucleotide pyrophosphatase/ phosphodiesterase 1

Junction adhesion molecule 2

Tissue inhibitor of metalloproteinase 3

Growh differentiation facto

Lysyl oxidase-like

Tissue inhibitor of metalloproteinase 3

Bone gamma carboxyglutamate protein 1 (Osteocalcin)

Secreted phosphoprotein 1 (Osteopontin)

Transient receptor potential cation channel, subfamily V, member 2

Procollagen lysine, 2-oxoglutarate 5-dioxygenase 2

Procollagen lysine, 2-oxoglutarate 5-dioxygenase 2

Tissue inhibitor of metalloproteinase 1

Sp transcription factor 7 (Osterix)

Collagen type II, alpha 1
A disintegrin-like and metallopeptidase (reprolysin-like) with throbmospondin type 1, motif 4

A disintegrin-like and metallopeptidase (reprolysin-like) with throbmospondin type 1, motif 4

Lysyl oxidase-like 2

Collagen type VI, alpha 2

Collagen type VI, alpha 2

Procollagen-proline, 2-oxoglutarate 4-dioxygenase (proline 4-hydroxylase), alpha II polypentide

Fig. 2. Osteoblast phenotypic markers responsive to Runx2 WT versus Runx $\Delta \mathrm{C}$ non-functional mutant as was detected by functional clustering of Affymetrix

Galanin receptor 2

Kiss 1 receptor (Gpr54)

Gtp binding protein 4

Small G-protein signaling modulator 3

Guanine nucleotide binding protein, alpha 13

Developmentally regulated GTP binding protein 2

G-protein coupled rement binding protein 1

G-protein coupled receptor 1376

Ral guanine nucleotide dissociation stimulator-like

G-protein-coupled estrogen receptor 1 (Gpr30)

cAMP responsive element binding protein 1

cAMP responsive element modulator
Regulator of G-protein signaling 5

Guanine nucleotide binding protein (G-protein), alpha q polypeptide

Regulator of G-protein signaling 16

Regulator of G-protein signaling 16

Regulator of G-protein signaling 16

-protein-coupled estrogen receptor, family $\mathrm{C}$, group 5 , member $\mathrm{B}$

Guanine nucleotide binding protein (G-protein), gamma 2

Adenylate cyclase ?

Adenylate cyclase

Guanine nucleotide binding protein (G-protein), gamma 2

Guanine nucleotide binding protein (G-protein), gamma

(G)

G-protein), gamma 12

denylate cyclase

gutor of G-protein signaling 2

RAS-related GPR, member F

G-protein-coupled estrogen receptor 124

Regulator of G-protein signaling 2

Sphingosine-1-phosphate receptor 2

Metallothionein 2

Regulator of G-protein signaling 5

Cathelicidin antimicrobial peptide

Cegulator 5

SRY-box containing gene 4

G-protein-coupled estrogen receptor 64

SRY-box containing gene 4
SRY-box containing gene 4

Regulator of G-protein signaling 4

Sphingosine-1-phosphate receptor

SRY-box containing gene 4
Regulator of G-protein signaling

Fig. 3. Runx2-responsive genes related to Gprotein coupled signaling in osteoprogenitors 


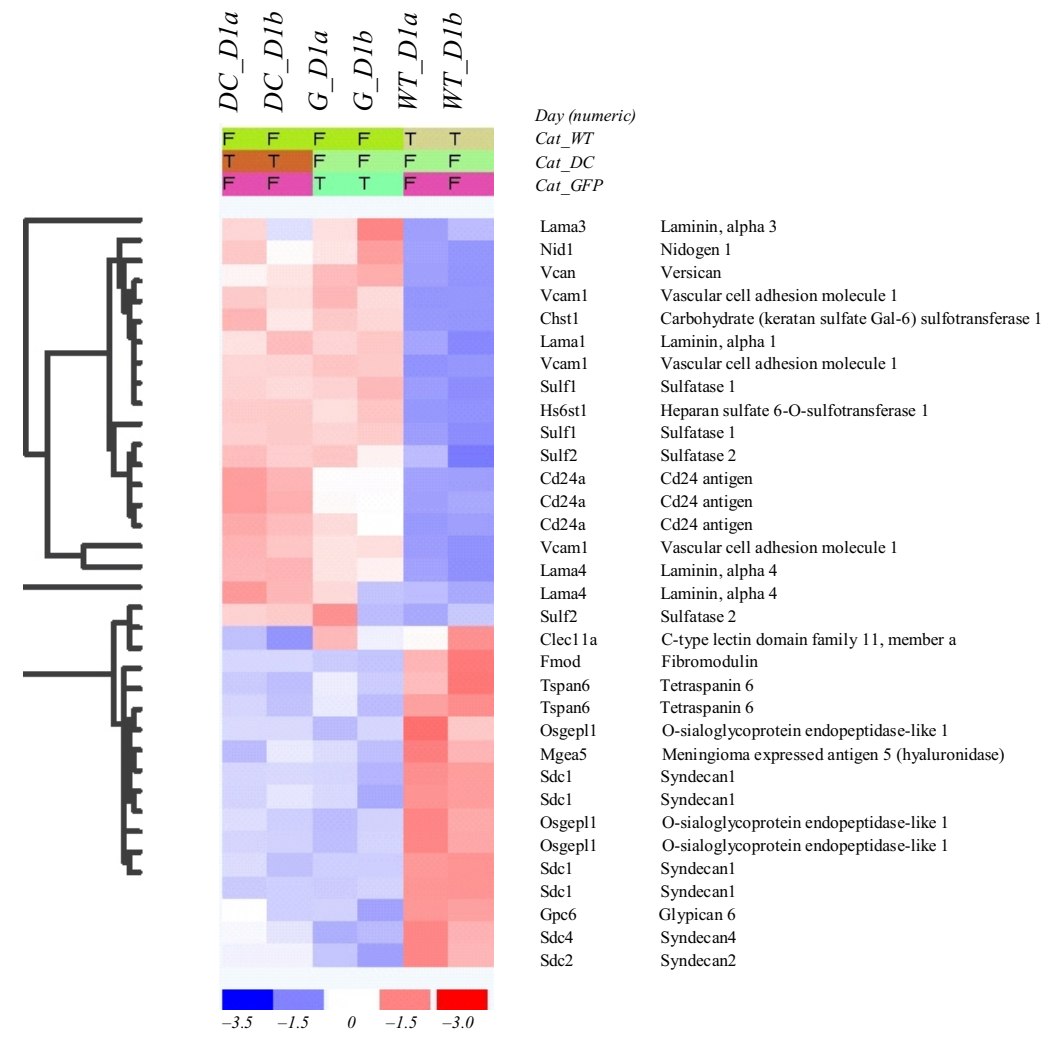

Fig. 4. Runx2-responsive genes related to $\mathrm{FGF}$ /proteoglycan signaling in osteoprogenitors

Day (numeric)

Cat_WT

Cat_DC

Cat_GFP

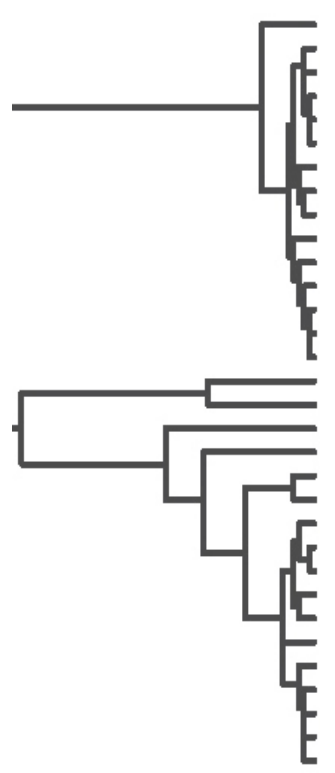

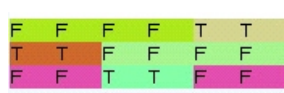

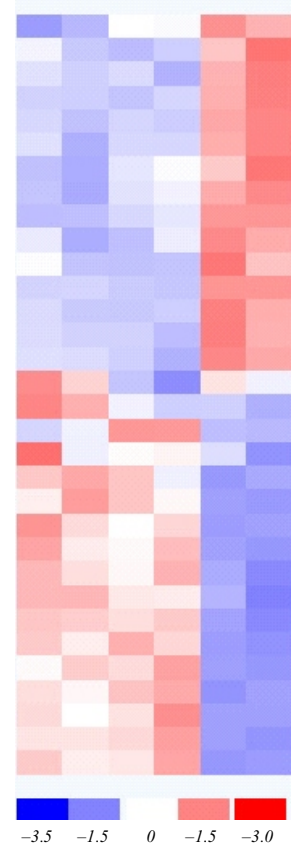

Sc5d

Lss

Tsc22d3

Cyp11al

Aldh3a1

Cyp39a1

Scarb

Fkbp4

Fdxr

Cyp51

Fdps

Dhcr7

Lss

Gper

Hsd3b7

Osbpl2

Zfp407

$\mathrm{Nr} 3 \mathrm{c} 1$

Ch25h

Nrip1
Osbpl3

Osbpl3

Cyp1b1

$\mathrm{Nr} 3 \mathrm{cl}$

Por

Ldlr

Cyp20a1

Osbpl6

Cyp1b1

$\mathrm{Nr} 3 \mathrm{c} 1$

$\mathrm{Nr} 3 \mathrm{c} 2$

$\mathrm{Nr} 3 \mathrm{c} 1$
Sterol-C5-desaturase homolog

Lanosterol synthase

Tsc22 domain family, member 3

Cytochrom $\mathrm{P} 450$, family 11 , subfamily a, polype
Aldehydedehydrogenase family 3 , subfamily A1

Cytochrom P450, family 39 , subfamily a, polypeptide 1

Scavenger receptor class $b$, member 1

Fk506 binding protein 4

Ferredoxin reductase

Cytochrom P450, family 51

Farnesyl diphosphate synthetase

7-dehydrocholesterol reductase

Lanosterol synthase

G-protein coupled estrogen receptor 1

Emopamil binding protein-like

Hydroxy-delta 5-sterol dehydrogenase 3-beta and steroid delta isomerase

Oxysterol binding protein-like 2

Zinc finger protein 407

Nuclear receptor subfamily 3 , group C, member 1

Cholesterol 25-hydroxylase

Nuclear receptor interacting protein 1

Oxysterol binding protein-like 3

Cytochrom P450, family 1 , subfamily b, polypeptide 1

Nuclear receptor subfamily 3 , group C, member 1

Cytochrome P450 oxidoreductase

Low density lipoprotein receptor

Cytochrom P450, family 20, subfamily a, polypeptide 1

Oxysterol binding protein-like 6

Cytochrom P450, family 1, subfamily b, polypeptide 1

Nuclear receptor subfamily 3 , group C, member 1

Nuclear receptor subfamily 3 , group $\mathrm{C}$, member 2

Nuclear receptor subfamily 3 , group C, member 1
Fig. 5. Runx2-responsive genes related to steroid hormones signaling and metabolism in osteoprogenitors 